\title{
System of Transliteration
}

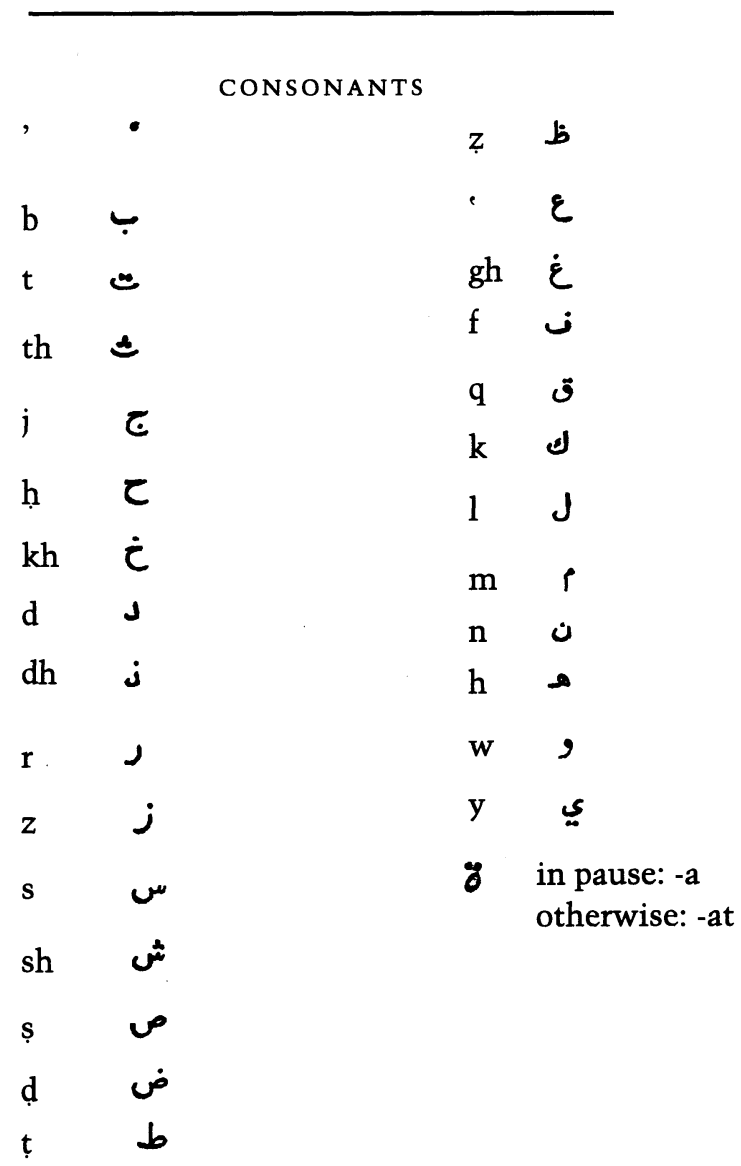

VOWELS

Short vowels

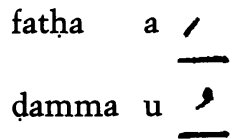

kasra i
Long vowels

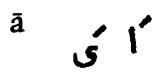

ù,

آ
Doubled uww (final: ū) "final: i)

Diphthongs aw

ay

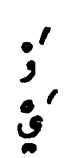


